"täyttymiseen" liittyvät aspektit että yhteiskunnallisena subjektina toimimisen aspektit.

Sivistyksen ja ratkaisujen etsinnän perinnettä kantaa ja vaalii tieteellinen tuottaja, kollektiivinen intellektuelle, joka sinnikkäästi jättäytyy kauppapaikoilta eikä pohdi myyntikikkoja. Subjektiviteettia sekä yhteiskuntaa ja ihmisen yhteiskunnallisuutta koskevan keskustelun ylläpitäminen on osa tieteellisen tuottajan työtä.

Airi Mäki-Kulmala

\title{
Post Symposium
}

Tutkijaliiton perustamisesta tuli viime vuonna kuluneeksi kymmenen vuotta. Liitto vietti vuosikymmenjuhlaansa seminaarein, joiden ohjelma täytti viisi marraskuun lopun päivää. Sarjan aloitti Fredric Jamesonin esitelmä sekä sitä seurannut keskustelu "Postmoderni - kapitalismin kulttuuri?" Sitä jatkoi kolmipäiväinen symposio "Marx Marxin jälkeen" ja sen päätti seminaari "Tiede työnä".

Juhlinnan ohessa pidettiin Tutkijaliiton liittokokous, jossa mm. uudistettiin säännöt.

Symposioiden aineisto hallitsee lehtemme tämän numeron artikkeliosastoa. Fredric Jameson luovutti käyttöömme ennen julkaisemattoman haastattelunsa, jonka on tehnyt Jamesonin kanssa Social Text -lehdessä työskentelevä Anders Stephanson. Myöhäiskapitalismin kulttuuriin liittyy myös toisen symposiovieraamme, tanskalaisen Hans-Jørgen Schanzin artikkeli. Länsisaksalaisen Georg Lohmannin sekä Jukka Gronowin tekstit ovat peräisin symposion Marx-istunnosta.

Vuosijuhlasymposioiden teemat painottuivat tällä kertaa ihmistieteisiin, mutta keskustelun monitieteisyyttä ja alojen rajat ylittävää ilmapiiriä todistaa $\mathrm{mm}$. tässä numerossa julkaisemamme aineisto. Liiton edustamat marxilaiset ja kriittiset tutkimusperinteet eivät tunnusta tieteenalakarsinoita. Palaamme symposioiden teemoihin tulevissa numeroissa.

Vuoden vaihtuessa myös lehtemme toimituksen koostumus muuttui. Kiitämme toimituksen eroavia jäseniä, erityisesti päätoimittaja Kaarlo Tuoria. Vankalla perustalla on helppo jatkaa eteenpäin. 